\title{
Risk Factors for Recurrent Aphthous Stomatitis: A Systematic Review
}

\author{
Factores de Riesgo para la Estomatitis Aftosa Recurrente: Revisión Sistemática
}

\author{
César Rivera' ${ }^{1}$ Antonieta Muñoz ${ }^{2}$; Carolina Puentes $^{2}$ \& Esteban Aguayo ${ }^{3}$
}

RIVERA, C.; MUÑOZ, A.; PUENTES, C. \& AGUAYO, E. Risk factors for recurrent aphthous stomatitis: a systematic review. Int. J. Morphol., 39(4):1102-1108, 2021.

SUMMARY: The cause and prevention of recurrent aphthous stomatitis (also called aphthous ulcers or canker sores) are still unknown. This may be due in part to ignorance of the risk factors present in susceptible people. In this systematic review (PROSPERO record \#CRD42019122214), we show that most of the risk factors for the disease are single nucleotide genetic polymorphisms in genes related to the functioning of immune system (TLR4, MMP9, E-selectin, IL-1 beta and TNF-alpha). Single nucleotide genetic polymorphisms do not constitute a modifiable risk. This indicates that, at least in part, susceptibility to recurrent aphthous stomatitis is hereditary, and that these factors cannot be modified.

KEY WORDS: Aphthous stomatitis; Risk factors; Genetic polymorphisms; Multivariate analysis, Systematic review.

\section{INTRODUCTION}

As many as 7 out of 10 people may experience recurrent aphthous stomatitis in their lives. Recurrent aphthous stomatitis are the most common ulcerative lesions of the oral mucosa (Rivera 2019). The exact etiology of recurrent aphthous stomatitis is unclear, but it is believed that there are several possible factors involved in its development. These include local factors, such as trauma, oral microbiota dysbiosis, hematinic deficiencies (iron, folic acid or vitamin B12), immunological factors and psychosocial stress (Akintoye \& Greenberg, 2014). In addition, a genetic predisposition could lead to the presence of ulcers. Positive family history can be found in up to $40 \%$ of patients (Slebioda et al., 2013). The chance for recurrent aphthous stomatitis is $90 \%$ when both parents are affected, but only $20 \%$ when neither parent has recurrent aphthous stomatitis (BMJ Best Practice, 2018). The recognition of certain family patterns of recurrent aphthous stomatitis has led to the discovery of genetic factors that have a pathogenic role. Genetic factors, and more specifically, genetic polymorphisms related to the functioning of the immune system, have recently been studied to determine their role in the development of oral ulcers (Dudding et al., 2019).
Despite the accumulated evidence, recurrent aphthous stomatitis ulcers are not preventable. This may be due in part to ignorance of the risk factors present in susceptible people. To predict and explain the risk of disease development, we must identify who is at risk and/or what would be an effective intervention (Schooling \& Jones, 2018). Risk factors are determinants associated with the increased risk of a disease. There are 3 types: variable, causal and fixed (cannot be modified) risk factors (Offord \& Kraemer, 2000). They can be genetic or an aspect of personal behavior, lifestyle or environmental exposure (Nature Portfolio, 2019). Risk factors play a central role in prediction and prevention (Offord \& Kraemer). Accordingly, statistical flows can be used to evaluate various independent variables and to determine their relevance in the presence or absence of a disease (Sedgwick \& Joekes, 2015).

Given that a wide variety of risk factors for the appearance of recurrent aphthous stomatitis has been reported in several studies over the years, the objective of this systematic review was to group the available data and summarize the risk factors associated with the development of ulcers.

\footnotetext{
${ }^{1}$ Molecular Pathology Laboratory, Department of Basic Biomedical Sciences, Faculty of Health Sciences, Universidad de Talca, Talca, 3460000, Chile.

${ }^{2}$ School of Dentistry, Faculty of Health Sciences, Universidad de Talca, Talca, 3460000, Chile.

${ }^{3}$ Faculty of Health Sciences, Universidad Arturo Prat, Iquique, 1100000, Chile.
} 


\section{MATERIAL AND METHOD}

General design. In this research, we conducted a systematic review (PROSPERO protocol registry \#CRD42019122214). The independent variables were the risk factors reported by the selected studies, and the dependent variable was the development of recurrent aphthous stomatitis. We established that a risk factor is a clinical characteristic, or a molecule obtained from an article that performed a binary logistic regression analysis or a Cox proportional hazards model. The power of a risk factor can be defined as the maximum discrepancy that can be achieved using the factor to divide the population into high- and low-risk groups (Offord \& Kraemer). In each selected article, there was a statistically significant association between the factor and the triggering of ulcers. The risk value should be reported as a comparison between a reference group (subjects without the factor) and the group with the risk factor (cases). A number greater than 1 indicates a high risk, and a number less than 1 indicates a low risk (protective factor).

Search strategy. We conducted a systematic search of all English-language literature in MEDLINE/PubMed until January 29, 2019. Our search strategy was the result of the combination of the following groups of keywords: 1) stomatitis aphthous OR Sutton disease and 2) risk factor OR epidemiologic studies OR odds ratio OR multivariate analysis OR logistic models OR risk.

Data extraction. The identification of research trends is useful to understand the thematic structure of a scientific domain. To understand the domains represented by all the identified articles in this study, we imported titles, summaries and keywords to the VOSviewer program (v.1.6.13, https:// www.vosviewer.com/). This program uses text mining to build and visualize networks of coincidence (joint appearance) of important terms extracted from a body of scientific literature (van Eck \& Waltman, 2017). Then, to filter the articles according to the research objectives, we analyzed titles and abstracts in the Rayyan online application (https://rayyan.qcri.org). This application was specifically developed to accelerate the initial selection of abstracts and titles through a semi-automated process (Ouzzani et al., 2016). We resolved the discrepancies by consensus.

Inclusion and exclusion criteria. We selected Englishlanguage articles that discussed human studies and that indicated a risk value for both the risk factor and the development of recurrent aphthous stomatitis. We excluded articles in which recurrent aphthous stomatitis was not the result of the study (outcome) and those that did not present an abstract, as well as studies whose objectives were therapeutic and those conducted in subpopulations (for example, people with HIV / AIDS). After the full-text evaluation, we excluded articles that did not perform multivariate analysis to assess risk, that did not specify the variables in the model, that did not have significant results (to report only relevant clinical results here), that did not specify the number of groups and that reported lesions outside the oral cavity (e.g., genital ulcers).

Articles included in the qualitative synthesis. We obtained the following information from the selected articles: reference, country, name of the risk factor, study design, technique and sample, number of subjects in the contrast groups, main conclusions, number of events within the groups, and risk values (including p-values and confidence intervals).

Quality evaluation. We performed the quality assessment using the Newcastle-Ottawa scale. This is a tool for assessing the risk of bias for observational studies (Lo et al., 2014). Three broad perspectives are evaluated: the selection of study groups; the comparability of the groups; and the determination of the exposure or outcome of interest for casecontrol or cohort studies, respectively. The evaluation scales are shown in supplementary file S1 (https://doi.org/10.5281/ zenodo.3533857). In our research, we used an adapted scale, wherein we assigned 1 point when the best criterion on the scale was met (Takahashi \& Hashizume, 2014). Scores 7-8, $5-6,4$ and $0-3$ classified the studies as very good quality, good quality, satisfactory, or unsatisfactory, respectively. Additionally, we evaluated the adherence of the reports to the STROBE guidelines (The Strengthening the Reporting of Observational Studies in Epidemiology). Here, we report the degrees of compliance as percentages (Limaye et al., 2018).

\section{RESULTS}

Filtered articles. The bibliometric map of all identified articles can be consulted in supplementary figure S1 (https:/ /doi.org/10.5281/zenodo.3533857). Of the identified articles, we excluded 201 that did not meet the eligibility criteria. We obtained 18 articles, of which we excluded 12 for different reasons, the main one being the absence of a multivariate model to assess risk (Fig. 1, PRISMA flow chart). The complete list of articles can be consulted in supplementary file S2 (http://doi.org/10.5281/ zenodo.3533857).

Risk factors are genetic polymorphisms in proinflammatory molecules. We examined the selected articles, 


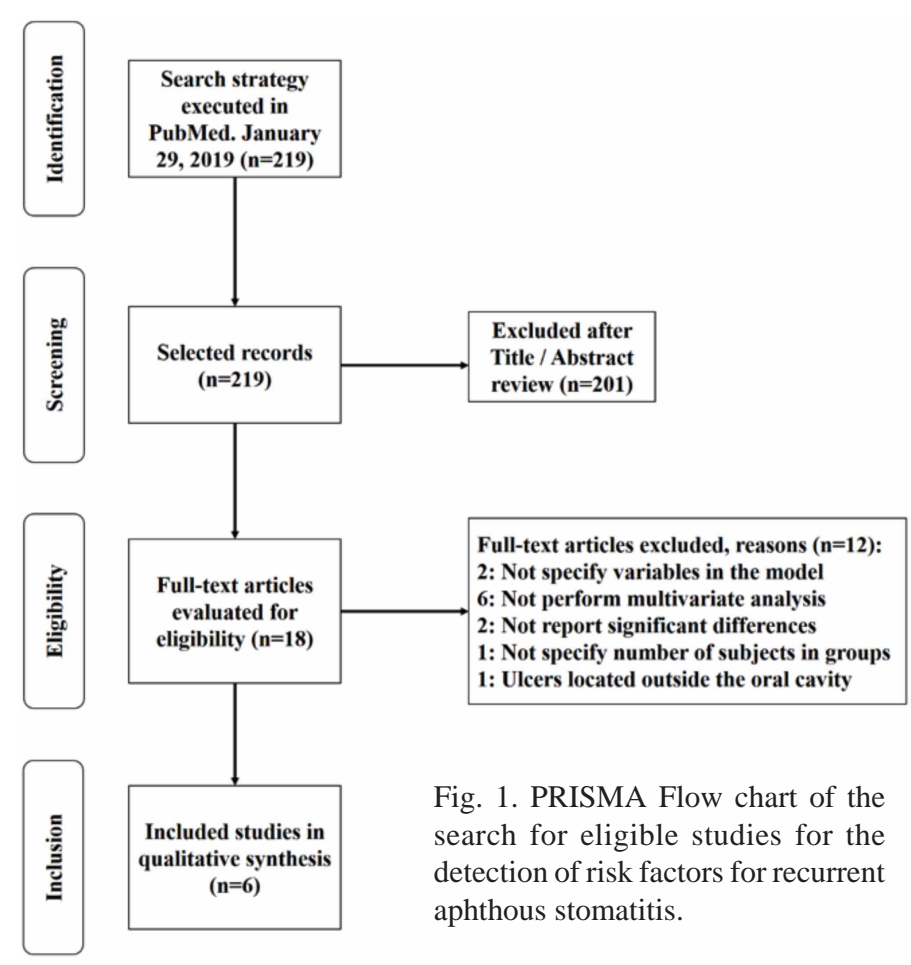

drawing out the main characteristics and conclusions. All studies were case-controlled and used adjusted OR to assess risk. Six articles evaluated 9 risk factors (Grady et al., 1992; Cicek et al., 2004; Guimaraes et al., 2007; Alkhateeb et al., 2013; Karasneh et al., 2014, 2015). Most of the risk factors identified were genetic polymorphisms evaluated by genotyping. These data are summarized in Table I. Different sample sizes were used, with a range from 128 to 11,360 . We obtained the number of subjects per group, as well as the risk values and confidence intervals of each one. The main results of the studies are presented in Table II. Eight clinicopathological variables were incorporated in 6 multivariate analyzes ( 6 studies generated 6 significant models and 24 covariates). The variables most commonly included for the adjustment of the models were age (6 models, $100 \%$ ), sex of the individuals (5 models, $83.3 \%$ ) and smoking habits (4 models, 66.7 \%). Supplementary file S2 (https://doi.org/10.5281/ zenodo.3533857) can be consulted for more details. In Table III, we present a narrative review of the identified risk factors.

Table I. Characteristics of included articles.

\begin{tabular}{|c|c|c|c|}
\hline Study & Factor & $\begin{array}{l}\text { Technique and } \\
\text { sample }\end{array}$ & Concluding remarks \\
\hline $\begin{array}{l}\text { Karasneh et al., } \\
\text { Jordan, } 2015 .\end{array}$ & $\begin{array}{l}\text { Toll-like receptor } 4 \text { polymorphism (TLR4, } \\
\text { rs } 10759931 \text {, genotype AA) }\end{array}$ & $\begin{array}{l}\text { Genotyping } \\
\text { Blood }\end{array}$ & $\begin{array}{l}\text { It would allow a more superficial presentation of } \\
\text { TLR4 in the oral epithelium of patients with RAS. }\end{array}$ \\
\hline $\begin{array}{l}\text { Karasneh et al., } \\
\text { Jordan, } 2014 .\end{array}$ & $\begin{array}{l}\text { Matrix metalloproteinase-9 polymorphism (MMP9, } \\
\text { rs } 11697325 \text {, genotype AA) }\end{array}$ & $\begin{array}{l}\text { Genotyping } \\
\text { Blood }\end{array}$ & $\begin{array}{l}\text { May lead to increased MMP-9 activity. This can } \\
\text { contribute to an increase in th e recruitment of } \\
\text { inflammatory cells and degradation of the } \\
\text { basement membrane. }\end{array}$ \\
\hline $\begin{array}{l}\text { Alkhateeb et a l., } \\
\text { Jordan, } 2013 .\end{array}$ & $\begin{array}{l}\text { E-selectin polymorphism (rs5361, genotype AA) } \\
\text { E-selectina poly morphism (rs5361, genotype AC) }\end{array}$ & $\begin{array}{l}\text { Genotyping } \\
\text { Blood }\end{array}$ & $\begin{array}{l}\text { It improves the recruitment of leukocytes and } \\
\text { recruited } \mathrm{T} \text { cells in response to a stimulus. }\end{array}$ \\
\hline $\begin{array}{l}\text { Guimarães et al., } \\
\text { Brazil, } 2007 .\end{array}$ & $\begin{array}{l}\text { Interleukin-1 beta polymorphism (IL-1 beta, } \\
\text { rs } 1143634 \text {, genotype CT) } \\
\text { Tumor necrosis factor-alfa polymorphism (TNF- } \\
\text { alfa, rs1800629, genotype GA) }\end{array}$ & $\begin{array}{l}\text { Genotyping } \\
\text { Oral mucosa }\end{array}$ & $\begin{array}{l}\text { A high production of IL-1 beta and TNF-alpha } \\
\text { facilitates the migration of inflammatory cells. }\end{array}$ \\
\hline \multirow[t]{2}{*}{$\begin{array}{l}\text { Ciçek et al., } \\
\text { Turkey, } 2004 .\end{array}$} & Manual laterality & $\begin{array}{l}\text { Self-report } \\
\text { Does not apply }\end{array}$ & $\begin{array}{l}\text { People who write with the left hand have a higher } \\
\text { number of im mune dis orders. }\end{array}$ \\
\hline & Smoke & & $\begin{array}{l}\text { In smokers, the keratinization of the oral mucosa } \\
\text { increases, which would constitute a barrier to the } \\
\text { possible etiological cause of RAS. }\end{array}$ \\
\hline $\begin{array}{l}\text { Grady et al., } \\
\text { United States, }\end{array}$ & Chewing tobacco & $\begin{array}{l}\text { Self-report } \\
\text { Does not apply }\end{array}$ & $\begin{array}{l}\text { It induces keratosis that can prevent RAS through } \\
\text { a local protective effect. }\end{array}$ \\
\hline
\end{tabular}

Description of selected studies by author, country, year, risk factor, technique, sample and main conclusions. Genetic polymorphisms correspond to different DNA sequences between individuals (Teama, 2018). All reported polymorphisms are genetic single nucleotide polymorphisms (SNPs). 
Table II. Extracted data from selected articles.

\begin{tabular}{|c|c|c|c|c|c|c|c|}
\hline Study & Factor & Groups & Frequencies* & & OR & P-value & CI \\
\hline $\begin{array}{l}\text { Karasneh } \text { et al., } \\
2015\end{array}$ & $\begin{array}{l}\text { Toll-like receptor } 4 \\
\text { poly morphism (TLR4, } \\
\text { rs10759931, genotype AA) }\end{array}$ & $\begin{array}{l}\text { RAS }(93 / 241) v s \text {. healthy } \\
(148 / 241)\end{array}$ & $\begin{array}{lll}\text { RAS } \quad(17 / 93) & v \\
\text { healthy }(13 / 148) & \end{array}$ & $v s$. & 3.89 & 0.0100 & $1.20-6.70$ \\
\hline $\begin{array}{l}\text { Karasneh et al., } \\
2014\end{array}$ & $\begin{array}{l}\text { Matrix metalloproteinase-9 } \\
\text { poly morphism (MMP9, } \\
\text { rs11697325, genotype AA) }\end{array}$ & $\begin{array}{l}\text { RAS }(96 / 249) v s \text {. healthy } \\
(153 / 249)\end{array}$ & $\begin{array}{l}\text { RAS }(29 / 96) \quad v \\
\text { healthy }(24 / 153)\end{array}$ & vs. & 3.11 & 0.0080 & $1.30-7.20$ \\
\hline \multirow[t]{2}{*}{$\begin{array}{l}\text { Alkhateeb } \text { et al., } \\
2013\end{array}$} & $\begin{array}{l}\text { E-selectin polymorphism } \\
\text { (rs5361, genotype AA) }\end{array}$ & $\begin{array}{l}\text { RAS (96/249) vs. healthy } \\
(153 / 249)\end{array}$ & $\begin{array}{l}\text { RAS }(75 / 96) v \\
\text { healthy }(102 / 249)\end{array}$ & $s$ & 10.90 & 0.0230 & $1.40-85.30$ \\
\hline & $\begin{array}{l}\text { E-selectina pol ymorphi sm } \\
\text { (rs5361, genotype AC) }\end{array}$ & $\begin{array}{l}\text { RAS (96/249) vs. healthy } \\
(153 / 249)\end{array}$ & $\begin{array}{l}\text { RAS }(19 / 96) \quad v \\
\text { healthy }(36 / 153)\end{array}$ & $v s$. & 9.00 & 0.0420 & $1.10-75.70$ \\
\hline \multirow[t]{2}{*}{$\begin{array}{l}\text { Guimarães et al., } \\
2007\end{array}$} & $\begin{array}{l}\text { Interleukin- } 1 \text { beta } \\
\text { poly morphism (IL-1 beta, } \\
\text { rs1143634, genotype CT) }\end{array}$ & $\begin{array}{l}\text { RAS }(64 / 128) v s . \text { healthy } \\
(64 / 128)\end{array}$ & $\begin{array}{l}\text { RAS } \quad(36 / 64) \\
\text { healthy }(23 / 64)\end{array}$ & $v s$. & 2.40 & 0.0300 & $1.11-5.20$ \\
\hline & $\begin{array}{l}\text { Tumor necrosis factor-alfa } \\
\text { poly morphism (TNF-alfa, } \\
\text { rs1800629, genotype GA) }\end{array}$ & $\begin{array}{l}\text { RAS (64/128) vs. healthy } \\
(64 / 128)\end{array}$ & $\begin{array}{l}\text { RAS }(22 / 64) v \\
\text { healthy }(10 / 64)\end{array}$ & $s$ & 3.07 & 0.0200 & $1.22-7.74$ \\
\hline \multirow[t]{2}{*}{ Ciçek et al., 2004} & Manual later ality & $\begin{array}{l}\text { Left }(761 / 11.360) v s . \\
\text { Right }(10.599 / 11.360)\end{array}$ & $\begin{array}{l}\text { Left (49/761) vs. } \\
\text { Right (254/10.599) }\end{array}$ & & 2.80 & 0.0001 & $2.05-3.84$ \\
\hline & Smoke & $\begin{array}{l}\text { Non-smokers } \\
(5.435 / 11.360) v s . \text { smokers } \\
(245 / 5.925)\end{array}$ & $\begin{array}{l}\text { Non-smokers } \\
(245 / 5.925) v s . \\
\text { smokers }(58 / 5.435)\end{array}$ & & 3.99 & 0.0001 & $2.99-5.34$ \\
\hline $\begin{array}{l}\text { Grady et al., } \\
1992\end{array}$ & Chewing tobacco & $\begin{array}{l}\text { Does not chew }(643 / 1.188) \\
v s . \text { chews }(545 / 1.188)\end{array}$ & $\begin{array}{l}\text { Does not chew } \\
(18 / 643) v s . \text { chews } \\
(7 / 545)\end{array}$ & & $0.40 * *$ & 0.0400 & Not reported \\
\hline
\end{tabular}

*First 4 articles report polymorphism frequencies of in RAS patients and healthy controls. Last 2 articles report the number of diagnoses in each factor. **Protective factor. OR, odds ratio; CI, $95 \%$ confidence interval. All values were reported as shown by each study.

Table III. Summary of proposed risk factors.

\begin{tabular}{|c|c|}
\hline Risk factor & Literature mining \\
\hline TLR4 & It specifically recognizes bacterial lipopolysaccharide, along with various other pathogen components and endogenous \\
\hline UniProt KB - O00206 & $\begin{array}{l}\text { molecules produced during abnormal situations, such as tissue damage (Vaure \& Liu 2014). Induce innate immune } \\
\text { responses. The rs } 10759931 \text { polymorphism is located in the promoter region of the gene (Kohailan et al., 2017). It } \\
\text { increases the gene expression of TLR4 (Tang et al., 2017). }\end{array}$ \\
\hline MMP9 & Degrades extracellular matrix proteins and activates cytokines and chemokines to regulate tissue remodeling \\
\hline UniProt KB - P14780 & $\begin{array}{l}\text { (Yabluchanskiy et al., 2013). The rs } 11697325 \text { polymorphism occurs in the } 5 \text { 'non-transcribed region of the gene } \\
\text { (which could have an enhancer or enhancer element) which increases transcription and the half-life of the protein } \\
\text { (Chen et al., 2006). }\end{array}$ \\
\hline E-selectin & It is expressed in endothelial cells after activation by IL-1 beta and TNF-alpha. It is important in the ext ravasation and \\
\hline UniProt KB & $\begin{array}{l}\text { accumulation of leukocytes in inflammatory responses (Silva et al., 2017). The rs5361 polymorphism occurs in the } \\
\text { exon of the gene. It alters the binding specificity of the extracellular domain of E-selectin, facilitating the bin ding of } \\
\text { its ligands, which in turn improves the adhesion of inflammatory cells to the vascular endothelium (Yararbas \& } \\
\text { Atalay 2018). }\end{array}$ \\
\hline IL-1 $\beta$ & It is a key mediator of the inflammatory response. It is essential for host response, resi stance to pathogens, and also \\
\hline UniProt KB - C9JVKO & $\begin{array}{l}\text { exacerbates damage during chronic disease and acute tissue injury (Lopez-Castejon \& B rough, 2011). The rs1143634 } \\
\text { polymorphism is associated with increased IL-1 } \beta \text { secretion in vitro (Wang \& Yuan 2019). }\end{array}$ \\
\hline TNF-al pha & It is one of the most potent pro-inflammatory cytokines and plays a role in tissue injury induced by the immune \\
\hline UniProt KB - & $\begin{array}{l}\text { response system (Wei et al., 2016). The rs1800629 polymorphism is found in the promoter region of the gene. This } \\
\text { leads to an increase in the level of expression of this cytokine (Li et al., 2013). }\end{array}$ \\
\hline Manual laterality & $\begin{array}{l}\text { Refers to the difference in skill between the hands as a result of biological factors, experience and training (van der } \\
\text { Feen et al., 2020). It has been suggested that writing with the left hand could be a marker of exposure in the womb to } \\
\text { high levels of testosterone, also associated with an increased risk of autoimmune and immune disorders (Gardener et } \\
\text { al., 2009). A link has recently been demonstrated between the rs } 386770867 \text { polymorphis m of the SETDB2 gene (a } \\
\text { strong candidate for mediating manual laterality) with asthma and other atopic diseases (Crespi et al., 2018). }\end{array}$ \\
\hline S moke/tobacco & $\begin{array}{l}\text { It is a risk factor for oral cancer. Produces hyperkeratosis of the oral epithelium and other potentially malignant } \\
\text { lesions (Naveen-Kumar et al., 2016; Hallikeri et al., 2018). }\end{array}$ \\
\hline
\end{tabular}

The information on each factor is described according to the literature review. SNPs can promote diseases, since they have the ability to influence the activity of the promoter region of a gene (gene expression), the conformation of messenger RNA (stability) and the subcellular localization of proteins (Shastry, 2009). This can help determine the likelihood that someone will develop a disease. For example, in Alzheimer's, apolipoprotein E contains two SNPs (rs4420638 and rs7412), which result in three possible alleles for its gene: e2, e3 and e4. Inheriting one copy of e4 carries a 2-3 times risk for Alzheimer's disease, while two copies (e4 / e4) increase the risk to 15 times (Liu et al., 2013). 
Chosen items are of good quality. We present the summary of the global evaluation of the articles in Table IV. Based on the Newcastle-Ottawa scale, 4 of the 6 studies are of very good quality and the remaining 2 are of good quality. These last two were carried out before 2007. Most reports analyzed according to the STROBE guidelines show good adherence to the key elements to be communicated (out of 18 out of 23 possible items). See supplementary file S3 (https://doi.org/10.5281/ zenodo.3533857) for more details.

Table IV. Quality of selected articles.

\begin{tabular}{lll}
\hline Study & Newcastle-Ottawa (score)* & STROBE (percentage)** \\
\hline Karasneh et al., 2015 & Good quality (6.0) & Poor adherence (39.1) \\
Karasneh et al., 2014 & Good quality (6.0) & Good adherence (82.6) \\
Alkhateeb et al., 2013 & Very good quality (7.0) & Excellent adherence (87.0) \\
Guimarães et al., 2007 & Very good quality (7.0) & Good adherence (78.3) \\
Ciç ek et al., 2004 & Very good quality (7.0) & Excellent adherence (95.7) \\
Grady et al., 1992 & Very good quality (7.0) & Excellent adherence (91.3)
\end{tabular}

*Newcastle-Ottawa Scale adapted to assess quality of studies according to Takahashi \& Hashizume (2014). **The STROBE items were evaluated according to the modified Limaye scale (Limaye et al., 2018).

\section{DISCUSSION}

In our research, we identified that most of the risk factors that determine individual susceptibility to thrush are genetic single nucleotide polymorphisms (SNPs). They are followed, as a protective factor, by exposure to tobacco.

We identified that SNPs in the TLR4, MMP9, Eselectin, IL-1 beta and TNF-alpha genes facilitate the migration of inflammatory cells in the context of recurrent aphthous stomatitis. In addition, two behavioral variables, manual laterality — apparently determined by a SNP (Crespi et al., 2018)-and smoking are associated with the development of lesions. According to our review of the literature (Table III), the factors other than smoking are fixed markers. To our knowledge, that gives little chance today for the prevention of recurrent aphthous stomatitis. This is because in complex diseases, a considerable number of people who are not carriers of an at-risk genotype can develop a disease due to environmental factors (Manolio \& Collins, 2009). Here, reported SNPs show a probability of between 2 to 11 times for the development of recurrent aphthous stomatitis. However, these numbers have limited usefulness if the trigger of the lesions is not known. We know, based on a small number of articles, that the subjects carrying the SNPs would be in a state of "sensitization." This is in line with the current view that proposes that genetic susceptibility to oral ulcers can lead to a disproportionate tissue response (Dudding et al.). That response is characterized by dysregulation of the local cell-mediated response, leading to an inappropriate focal accumulation of cytotoxic T lymphocyte populations within the oral mucosa after minor triggers. This, in turn, leads to tissue damage and clinical manifestations such as oral ulceration (Akintoye \& Greenberg; Rivera, 2019).
In addition to the fact that SNPs do not constitute a modifiable risk, the evidence that showed that smokers or tobacco chewers had fewer recurrent aphthous stomatitis. This evidence is reinforced with results stating that aphthous ulcers are a common result in people who quit smoking (McRobbie et al., 2004). The habit of smoking or chewing tobacco produces an increase in the keratinization of the oral mucosa (Sawair, 2010). This keratinization protects the oral tissues against the penetration of the possible etiological agent of recurrent aphthous stomatitis. Additionally, nicotine or its metabolites decrease pro-inflammatory cytokines such as IL-1 beta, TNF-alpha, and increase the anti-inflammatory cytokine IL-10 (Subramanyam, 2011). These facts suggest an immunosuppressive or reducing role for the inflammatory response in smoking. However, from a clinical point of view, the recommendation to use this habit as a protective factor is not viable. This is not compatible with the general advice given by health professionals about the harmful effects of tobacco use and smoking, and is even less so when smoking is the main risk factor for lung cancer (Walser et al., 2008) and for oral cancer (Rivera, 2015).

Although more than 200 articles were initially recovered, only a small portion of them were included in our analyses. A large number were excluded because, although they reported significant relationships, these associations were the result of bivariate analyses. Furthermore, most of the articles did not report risk values after a multivariate analysis. Variables that are significant in bivariate analyses may become insignificant in a multivariate model. This critical point has been previously explained in the case of recurrent aphthous stomatitis and cigarettes, where the association reported in most articles may be due 
to the lack of adjustment to other clinical antecedents, such as age, the number of cigarettes consumed, depression or stress when quitting the habit (Sawair). Multivariate techniques allow researchers to observe the relationships between factors in a general way and to quantify the relationship between them. They specify the conditions under which an association takes place. Compared with bivariate analyses, multivariate techniques provide a more powerful test of significance (Jackson, 2018). Therefore, despite the fact that our conclusions come from a small number of articles, the evidence provided by the articles included in our synthesis is reliable. In addition, all the articles are of good or very good quality, showing good adherence to the formal characteristics that they must meet to report the results.

The etiology and pathogenesis of recurrent aphthous stomatitis remain unclear. The prominence of SNPs in what we call a state of sensitization shows that this disease corresponds in part to a genetic disorder.

\section{CONCLUSION}

Taken together, our results show that there is a group of hereditary fixed markers associated with the development of lesions, which probably make subjects who possess them susceptible to disproportionate focal immune responses in the oral mucosa.

\section{ACKNOWLEDGMENTS}

This research was funded by ANID FONDECYT Iniciación num. \#11180170 (to C.R.) and Concurso de Proyectos de Investigación de Alto Nivel en Odontología, Red Estatal de Odontología num. \#RE019-012 (to C. R).

AUTHORS' CONTRIBUTIONS. Conceptualization, C.R. and E.A.; methodology, C.R., A.M., and C.P.; software C.R., A.M., and C.P.; validation, C.R., E.A., A.M., and C.R.; investigation, C.R., A.M., and C.P.; data curation, C.R.; writing-original draft preparation, C.R., E.A., A.M., and C.R.; writing-review and editing, C.R., E.A., A.M., and C.R.; supervision, C.R.; project administration, C.R.; funding acquisition, C.R and E.A. All authors have read and agreed to the published version of the manuscript.

Availability of data and materials. All data sets generated or analyzed during the study are included in the published article. The following are available online at http:/ /doi.org/10.5281/zenodo.3533857, Figure S1: thematic structure of the identified article, File S1: Newcastle-Ottawa scale, File S2: PRISMA Steps, File S3: Newcastle-Ottawa and STROBE evaluation.

RIVERA, C.; MUÑOZ, A.; PUENTES, C. \& AGUAYO, E. Factores de riesgo para la estomatitis aftosa recurrente: Revisión sistemática. Int. J. Morphol., 39(4):1102-1108, 2021.

RESUMEN: Aún se desconoce la causa y cómo prevenir la estomatitis aftosa recurrente (más conocida como aftas). En esta revisión sistemática (registro PROSPERO \#CRD42019122214) mostramos que la mayoría de los factores de riesgo para la enfermedad son polimorfismos genéticos de un solo nucleótido en genes relacionados con el funcionamiento del sistema inmune (TLR4, MMP9, Eselectin, IL-1 beta y TNF-alfa). Los polimorfismos genéticos de un solo nucleótido no constituyen un riesgo modificable.Ello indica que, al menos en parte, la susceptibilidad para las aftas es hereditaria y que esos factores no pueden ser modificados.

PALABRAS CLAVE: Estomatitis aftosa; Factores de riesgo; Polimorfismo genético; Análisis multivariante; Revisión sistemática.

\section{REFERENCES}

Akintoye, S. O. \& Greenberg, M. S. Recurrent aphthous stomatitis. Dent. Clin. North. Am., 58(2):281-97, 2014.

Alkhateeb, A.; Karasneh, J.; Abbadi, H.; Hassan, A. \& Thornhill, M. Association of cell adhesion molecule gene polymorphisms with recurrent aphthous stomatitis. J. Oral Pathol. Med., 42(10):741-6, 2013.

BMJ Best Practice. Oral Aphthous ulcers. BMJ Website, 2018. Available from: https://bestpractice.bmj.com/topics/en-gb/564

Chen, L.; Wang, X.; Carter, S. A.; Shen, Y. H.; Bartsch, H. R.; Thompson R. W.; Coselli, J. S.; Wilcken, D. L.; Wang, X. L. \& LeMaire, S. A. A single nucleotide polymorphism in the matrix metalloproteinase 9 gene $(-8202 \mathrm{a} / \mathrm{g})$ is associated with thoracic aortic aneurysms and thoracic aortic dissection. J. Thorac. Cardiovasc. Surg., 131(5):1045-52, 2006.

Cicek, Y.; Canakci, V.; Ozgoz, M.; Ertas, U. \& Canakci, E. Prevalence and handedness correlates of recurrent aphthous stomatitis in the turkish population. J. Public Health Dent., 64(3):151-6, 2004.

Crespi, B.; Read, S. \& Hurd, P. The setdb2 locus: Evidence for a genetic link between handedness and atopic disease. Heredity (Edinb)., 120(1):77-82, 2018.

Dudding, T.; Haworth, S.; Lind, P. A.; Sathirapongsasuti, J. F.; Tung, J. Y.; Mitchell, R.; Colodro-Conde, L.; Medland, S. E.; Gordon, S.; Elsworth, B.; et al., Genome wide analysis for mouth ulcers identifies associations at immune regulatory loci. Nat. Commun., 10(1):1052, 2019.

Gardener, H.; Munger, K.; Chitnis, T.; Spiegelman, D. \& Ascherio A. The relationship between handedness and risk of multiple sclerosis. Mult. Scler, 15(5):587-92, 2009.

Grady, D.; Ernster, V. L.; Stillman, L. \& Greenspan, J. Smokeless tobacco use prevents aphthous stomatitis. Oral Surg. Oral Med. Oral Pathol., 74(4):463-5, 1992.

Guimaraes, A. L.; Correia-Silva, J. de F.; Sa, A. R.; Victoria, J. M.; Diniz, M. G.; Costa, F. de O. \& Gomez, R. S. Investigation of functional gene polymorphisms il-1beta, il-6, il-10 and tnf-alpha in individuals with recurrent aphthous stomatitis. Arch. Oral Biol., 52(3):268-72, 2007. 
Hallikeri, K.; Naikmasur, V.; Guttal, K.; Shodan, M. \& Chennappa, N. K. Prevalence of oral mucosal lesions among smokeless tobacco usage: A cross-sectional study. Indian J. Cancer, 55(4):404-9, 2018.

Jackson, J. Multivariate Techniques: Advantages and Disadvantages. The Classroom, Website, 2018. Available from: https:// www.theclassroom.com/multivariate-techniques-advantagesdisadvantages-8247893.html

Karasneh, J. A.; Bani-Hani, M. E.; Alkhateeb, A. M.; Hassan, A. F. \& Thornhill, M. H. Association of mmp but not timp-1 gene polymorphisms with recurrent aphthous stomatitis. Oral Dis., 20(7):693-9, 2014.

Karasneh, J.; Bani-Hani, M.; Alkhateeb, A.; Hassan, A.; Alzoubi, F. \& Thornhill, M. Tlr2, tlr4and cd86 gene polymorphisms in recurrent aphthous stomatitis. J. Oral Pathol. Med., 44(10):857-63, 2015.

Kohailan, M.; Alanazi, M.; Rouabhia, M.; Al Amri, A.; Parine, N. R. \& Semlali, A. Two snps in the promoter region of toll-like receptor 4 gene are not associated with smoking in saudi arabia. Onco. Targets Ther, 10:745-52, 2017.

Li, M.; Han, Y.; Wu, T. T.; Feng, Y. \& Wang, H. B. Tumor necrosis factor alpha rs 1800629 polymorphism and risk of cervical lesions: A metaanalysis. PLoS One, 8(8):e69201, 2013.

Limaye, D.; Limaye, V.; Pitani, R. S.; Fortwengel, G.; Sydymanov, A.; Otzipka, C. \& Ziesenis, P. Development of a quantitative scoring method for strobe checklist. Acta Pol. Pharm., 75(5):1095-106, 2018.

Liu, C. C.; Liu, C. C.; Kanekiyo, T.; Xu, H. \& Bu, G. Apolipoprotein e and alzheimer disease: Risk, mechanisms and therapy. Nat. Rev. Neurol., 9(2):106-18, 2013.

Lo, C. K.; Mertz, D. \& Loeb, M. Newcastle-ottawa scale: Comparing reviewers' to authors' assessments. BMC Med. Res. Methodol., 14:45, 2014.

Lopez-Castejon, G. \& Brough D. Understanding the mechanism of il1beta secretion. Cytokine Growth Factor Rev., 22(4):189-95, 2011.

Manolio, T. A. \& Collins, F. S. The hapmap and genome-wide association studies in diagnosis and therapy. Annu. Rev. Med., 60:443-56, 2009.

McRobbie, H.; Hajek, P. \& Gillison, F. The relationship between smoking cessation and mouth ulcers. Nicotine Tob. Res., 6(4):655-9, 2004.

Nature Portfolio. Risk factors. Website, Nature, 2019. Available from: https://www.nature.com/subjects/risk-factors

Naveen-Kumar, B.; Tatapudi, R.; Sudhakara-Reddy, R.; Alapati, S.; Pavani, K. \& Sai-Praveen, K. N. Various forms of tobacco usage and its associated oral mucosal lesions. J. Clin. Exp. Dent., 8(2):e172-7, 2016.

Offord, D. R. \& Kraemer, H. C. Risk factors and prevention. Evid. Based Mental Health, 3(3):70-1, 2000.

Ouzzani, M.; Hammady, H.; Fedorowicz, Z. \& Elmagarmid, A. Rayyana web and mobile app for systematic reviews. Syst. Rev., 5(1):210, 2016.

Rivera, C. Essentials of oral cancer. Int. J. Clin. Exp. Pathol., 8(9):1188494, 2015.

Rivera, C. Essentials of recurrent aphthous stomatitis. Biomed. Rep., 11(2):47-50, 2019.

Sawair, F. A. Does smoking really protect from recurrent aphthous stomatitis? Ther. Clin. Risk Manag., 6:573-7, 2010.

Schooling, C. M. \& Jones, H. E. Clarifying questions about "risk factors": Predictors versus explanation. Emerg. Themes Epidemiol., 15:10, 2018.

Sedgwick, P. \& Joekes, K. What are the risks? BMJ, 350:h2931, 2015.

Shastry, B. S. Snps: Impact on gene function and phenotype. Methods Mol. Biol., 578:3-22, 2009

Silva, M.; Videira, P. A. \& Sackstein, R. E-selectin ligands in the human mononuclear phagocyte system: Implications for infection, inflammation, and immunotherapy. Front. Immunol., 8:1878, 2017.

Slebioda, Z.; Szponar, E. \& Kowalska, A. Recurrent aphthous stomatitis: Genetic aspects of etiology. Postepy Dermatol. Alergol., 30(2):96-102, 2013.

Subramanyam, R. V. Occurrence of recurrent aphthous stomatitis only on lining mucosa and its relationship to smoking--a possible hypothesis. Med. Hypotheses, 77(2):185-7, 2011.
Takahashi, N. \& Hashizume, M. A systematic review of the influence of occupational organophosphate pesticides exposure on neurological impairment. BMJ Open, 4(6):e004798, 2014.

Tang, A. T.; Choi, J. P.; Kotzin, J. J.; Yang, Y.; Hong, C. C.; Hobson, N.; Girard, R.; Zeineddine, H. A.; Lightle, R.; Moore, T.; et al., Endothelial tlr4 and the microbiome drive cerebral cavernous malformations. Nature, 545(7654):305-10, 2017.

Teama, S. DNA Polymorphisms: DNA-Based Molecular Markers and their Application in Medicine. In: Liu, Y. (Ed.). Genetic Diversity and Disease Susceptibility. Rijeka, IntechOpen, 2018.

van der Feen, F. E.; Zickert, N.; Groothuis, T. G. G. \& Geuze, R. H. Does hand skill asymmetry relate to creativity, developmental and health issues and aggression as markers of fitness? Laterality, 25(1):53-86, 2020.

van Eck, N. J. \& Waltman, L. Citation-based clustering of publications using citnetexplorer and vosviewer. Scientometrics, 111(2):1053-70, 2017.

Corresponding author:

Dr. César Rivera, DDS, MSc, PhD

Department of Basic Biomedical Sciences

Faculty of Health Sciences

University of Talca North Campus

Lircay Av. S/N, Office No. 8,

Talca, Maule Region 3460000

CHILE

E-mail cerivera@utalca.cl

Received : 26-03-2021

Accepted : 06-05-2021 